\title{
INTERNATIONAL COMPETITION LAW HARMONISATION AND THE WTO: PAST, PRESENT AND FUTURE
}

\author{
Working paper
}

To be presented by Dr Jurgita Malinauskaite during the Workshop “Theory and Practice of Harmonisation” held at the IALS, on 24-26 June 2008

\section{Introduction}

The globalisation process together with technological advancements, dilution of trade barriers and liberalisation as well as privatisation programs have shaped the global landscape, which has resulted in the augmentation of cross-border businesses. The expansion of businesses beyond the national borders has raised the issues of international anti-competitive practices. On the one hand, businesses are becoming international, whereas competition laws are national with their curbs and limits. Due to these boundaries, national competition authorities are unable to address international anti-competitive behaviour effectively, especially if the authority lacks experience, knowledge or resources and does not have vision when the anticompetitive issues are transcending their domestic boundaries. As a result, some international anti-competitive transactions can escape any regulatory mechanism. On the other hand, globalisation and therefore international anti-competitive practices have driven competition authorities to apply their laws beyond national boundaries. Many countries have introduced the extra-territoriality principle, where national competition authorities apply their domestic law to extra-territorial conduct that has effects in their nations. Hence, extra-territorial effects of competition bring various countries competition laws into contact and quite often in confrontation. Apart from the harm that may be caused to the relationship between the different countries, conflicting results may be damaging to the firms concerned, who usually are agitated if their transactions are subjected by various competition authorities. For instance, if a cross-border merger was approved by one side of the Atlantic, but blocked by the other, this conflicting result would place an unnecessary burden on the undertakings involved. Firms are concerned about the cost of their international transactions due to these conflicting or duplicative policies by different national competition authorities. Problems in dealing with these cross-border challenges have brought scholars and 
practitioners as well as various international organisations together to discuss harmonisation of international competition law and its importance in today's global world. Hence, this article will discuss the prospect of harmonisation of international competition law in the light of the WTO, its past, present and future. It will also evaluate the benefits and the pitfalls of international competition law, as to whether the notion of "one size fits all" could be the best solution for competition law in an international context, especially from the position of small and developing countries. The question will be raised as to what are the strengths and limitations of the WTO in harmonising and enforcing international competition law.

\section{Globalisation and competition policy}

The globalisation process together with technological advancements, domestic government policies with the opening up of borders for foreign traders and signing up to the international and/or regional organisations, dilution of trade barriers and customs distortions, liberalisation of capital movement and investment, and privatisation programs have changed the global landscape over time, where global transactions whirl over national borders bringing businesses together. As markets and competition become increasingly international, so do anti-competitive practices by firms. The international dimension of competition challenges has become more prominent. The difference between national and international anti-competitive practices lies in the cross-border dimension of anti-competitive behaviour, which is harder to challenge. The examples of anti-competitive practices that can cause global economic damage are international anti-competitive agreements or concerted practices, anti-competitive merger transactions with spill-over effects and abuse of global dominant firms. Practices of this nature can lead to the transfer of wealth from consumers in one country to producers in another. Consequently, consumers in one or more countries will bear directly or indirectly the cost of these unlawful activities, which may result in higher prices and reduced choice. Competition law together with competition enforcement institutions were introduced to many jurisdictions in the world. However, the governments from different jurisdictions have soon realised that national competition law could not give a final solution as trade has been increasing globally whereas competition law is national. In a global world where multinational firms become dominant, national competition authorities face difficulties in regulating 
these cross-border anti-competitive activities. While domestic markets are regulated by national authorities through their competition law or other measures, there is hardly any mechanism for regulating the international market with regard to competition law issues.

Globalisation has significant impact for competition policy and law in the global economy; it has almost made it inevitable to change competition law. As a response to these international competition issues, the harmonisation of international competition law has evolved into a topic of significant contemporary importance. Scholars and practitioners around the world have questioned whether there is a necessity to set up a global competition agency in order to enforce international competition law and if yes, which one international body is the most suitable and what role should it play in order to enforce the principles of international competition. Many organisations, such as the International Competition Network (the ICN) ${ }^{1}$, the Organisation for Economic Cooperation and Development (the OECD) ${ }^{2}$, the United Nations Conference on Trade and Development (the UNSTAD) ${ }^{3}$ and others have considered or even introduced soft law to deal with international competition issues. The Wold Trade Organisation (the WTO) is not an exception.

\footnotetext{
${ }^{1}$ The ICN is devoted exclusively to competition law enforcement. Although, it does not exercise any rule-making function, the ICN can issue recommendations or "best practices" and then individual competition authorities decide whether and how to implement the recommendations, through unilateral, bilateral or multilateral arrangements, as appropriate. For further information, see web-site: http://www.internationalcompetitionnetwork.org

${ }^{2}$ The OECD has been active in encouraging soft convergence amongst member countries by adopting a number of non-binding Recommendations on competition law and policy. For instance, OECD Guiding Principles for Regulatory Quality and Performance (2005), Best Practices for the Formal Exchange of Information Between Competition Authorities in Hard Core Cartel Investigations (2005), Recommendation of the Council concerning merger review (2005), Recommendation of the Council concerning structural separation in regulated industries (2001), Recommendation of the Council concerning effective action against hard core cartels (1998), and Recommendation of the Council concerning co-operation between member countries on anticompetitive practices affecting international trade (1995). For further discussion, see web-site: http://www.oecd.org/document/59/0,3343,en_2649_34535_4599739_1_1_1_1,00.html

${ }^{3}$ The UNCTAD provides national competition authorities from developing countries and economies in transition with an intergovernmental forum for addressing practical competition law and policy issues. It is also a depository of international competition legislations, the Model Law on Competition (TD/RBP/Conf.5/7/Rev.2)and the United Nations Set of Principles on Competition ((td/rbp/conf/10/rev.2) 01/01/01).
} 


\section{Competition issues and the predecessors of the WTO}

Despite the absence of binding competition rules within the WTO, competition issues have been an important question within the international trading system for some time. Already in 1948 the draft of the 1948 Havana Charter, which was aimed at establishing the International Trade Organisation (the ITO), addressed issues on restrictive business practices. Article 46 of the Charter imposed an obligation on member countries to prevent firms from engaging in activities that 'restrain competition, limit access to markets or foster monopolistic control whenever such practices have harmful effects on the expansion of production or trade, ${ }^{\text {. }}$ However, the ITO never materialised and the Charter was deemed to fail after the US Senate objected partly because the US's concern over inability to enforce its own antitrust law. All that survived after the ITO was the General Agreement on Tariffs and Trade (the GATT ${ }^{5}$ ), which in 1995 was superseded by the $\mathrm{WTO}^{6}$. The GATT was designed to provide a general framework that encouraged free trade between contracting nations by regulating and reducing tariffs on traded goods and by providing a common mechanism for resolving trade disputes. The explicit aim of GATT is to eliminate all trade restrictions. Article III (para 4) of the GATT provides that "[..] the products of the territory of any contracting party imported into the territory of any other contracting party shall be accorded treatment no less favourable than that accorded to like products of national origin”. Although the GATT prohibits trade restrictions on international trade, it does not directly address anti-competitive issues ${ }^{7}$. Nonetheless, the contracting parties adopted a decision that the members should consult with each other concerning allegedly restrictive business practices $^{8}$. The GATT helped to establish a strong and prosperous multilateral trading system that became more liberal through rounds of trade negotiations; however, by

\footnotetext{
${ }^{4}$ Havana Charter for an International Trade Organization, UN Doc. E/Conf.2?78 1948, available from web-site: http://www.worldtradelaw.net/misc/havana.pdf

${ }^{5}$ General Agreement on Tariffs and Trade, 1947, 61 Stat. A-11, T.I.A.S. 1700, 55 U.N.T.S. 194.

${ }^{6}$ For further discussion, see C. Wilcox, A Charter for World Trade, 1949 and W.A. Brown, Jr, The United States and the Restoration of World Trade, 1950.

${ }^{7}$ Though several articles to some extent address anti-competitive issues, for instance, article III on National Treatment; article XI on prohibition of quantitative restrictions; article VIII of GATS on monopoly service supplier providers etc.

${ }^{8}$ Decision on Restrictive Business Practices: Arrangements for Consultations, November 18, 1960, GATT, B.I.S.D. ( $9^{\text {th }}$ Supp.) at 28.
} 
1980s the system needed to be reformed. This led to the Uruguay Round and subsequently to the WTO.

\section{Competition issues and the WTO}

In 1995 the GATT was superseded by the World Trade Organisation (the WTO). The WTO is an organisation that deals with the rules of trade between nations at a global or near-global level. It has a multi-functional task being an organisation for liberalising trade, a forum for governments to negotiate trade agreements, and a place to settle trade disputes ${ }^{9}$. Despite these roles, the WTO is not Superman and cannot solve all the world's problems. This can be seen from a limited power of the WTO dispute settlement to deal with competition issues. The globalisation process has brought trade law and competition law into contact; anti-competitive practices have been recognised by some scholars ${ }^{10}$ as the next 'generation' of barriers to trade in the world. Anti-competitive behaviour by private firms that can affect the flows of trade and investment between countries has increased in recent years. Although the efforts of the international community have been on removing barriers to the flow of trade, anti-competitive practices of firms that hinder the expansion of world trade have not been left unnoticed. The first WTO Ministerial Conference in Singapore in 1996 formed the Working Group on the Interaction between Trade and Competition Policy "to study issues raised by Members relating to the interaction between trade and competition policy, including anti-competitive practices, in order to identify any areas that may merit further consideration in the WTO framework" ${ }^{11}$. This Group was given a mandate to explore these issues with the possibility of negotiating an agreement. It meant to cover a wide range of issues, including the impact of competition on trade and vice versa the impact of trade policy on competition, gathering information from member countries and evaluating alternatives of

\footnotetext{
${ }^{9}$ For further reading, see web-site: http://www.wto.org/english/thewto_e/whatis_e/tif_e/fact1_e.htm (accessed 10/06/2008)

${ }^{10}$ See, for instance, K. Lee, The WTO dispute settlement and anti-competitive practices: lessons learnt from trade disputes, the University of Oxford press, Working paper, 10/05.

${ }^{11}$ WTO, Singapore Ministerial Declaration, Conference Doc WT/MIN(96)/DEC/W 13 December 1996, 96-5315, at para 20. For further discussion, see web-site: http://www.wto.org/english/thewto_e/minist_e/min96_e/min96_e.htm (accessed 10/06/2008)
} 
international co-operations ${ }^{12}$. This promising start can be further seen in the Doha Ministerial Declaration, where Ministers "recognized the case for a multilateral framework to enhance the contribution of competition policy to international trade and development, and the need for enhanced technical assistance and capacitybuilding in this area"13. They instructed the Working Group to focus on the clarification of the following: core principles, including transparency, nondiscrimination and procedural fairness; hardcore cartels; modalities for voluntary cooperation; and support for reinforcement of competition authorities in developing countries through capacity building. Unfortunately, during the subsequent meetings, members failed to reach a consensus on the content of possible competition rules, with much of the opposition coming from small and developing countries that feared intrusive competition law enforcement designed by developed countries. Thus, negotiations on competition policy ended in deadlock at the Cancun Ministerial Conference in 2003. According to Stewart, this was because of a range of political issues rather than technical objections to a multilateral framework for competition policy in the $\mathrm{WTO}^{14}$. With a promising start, the last step adopted by the WTO is rather disappointing. In the so called “July 2004 package” the WTO General Council marked that the issue of competition policy "will not form part of the Work Programme set out in that Declaration and therefore no work towards negotiations on any of these issues will take place within the WTO during the Doha Round" ${ }^{\text {. }}$ Hence, the Working Group is currently inactive and the Doha Round of multilateral trade negotiations, launched in November 2001 under the aegis of the WTO, remains stalled. According to Jackson, the WTO's reluctance to explicitly address competition policy could be explained by various constitutional and procedural constraints ${ }^{16}$. For example, it is difficult to harmonise existing national regimes into a single standard, especially since national competition policies not only employ different standards but

\footnotetext{
${ }^{12}$ M.Yun, Trade and Competition Policy in WTO, Chapter 7, In: Regional Perspectives on the WTO Agenda: Concerns and common Interests, pp. 122, available from web-site: http://www.unescap.org/tid/publication/chap7_2161.pdf

${ }^{13}$ WTO, Doha Ministerial Declaration, WT/MIN(01)/DEC/W/1 14 November 2001, at paras 23-25, available from web-site: http://www.wto.org/english/tratop_e/comp_e/history_e.htm

${ }^{14}$ For further discussion, see T. Stewart, The Fate of Competition Policy in Cancun: Politics or Substance?, 2004 31(1) Legal Issues of Economic Integration 7.

${ }^{15}$ WTO, The General Council’s post-Cancun decision, the “July 2004 package”, WT/L/579 2 August 2004, at para (g), available from web-site: http://www.wto.org/english/tratop_e/dda_e/draft_text_gc_dg_31july04_e.htm

${ }^{16}$ J. Jackson, Sovereignty, the WTO, and Changing Fundamentals of International Law, Cambridge university press, 2006.
} 
also require complex factual determinations of changed performance in specific markets as a result of designated actions, for instance, for tying agreements, parallel import restrictions, and merger transaction deals. Despite this deadlock at the WTO, the following section will discuss the possible benefits that international competition law may offer.

\section{Benefits of international competition law harmonisation and the WTO}

Due to the globalisation process, there has been a significant rise in the number of large cross-border transactions, potentially requiring clearance from a multitude of national competition authorities. Also, the detection of anti-competitive practices, for instance, in hard-core cartel cases or merger transactions with spill-over effects, affecting multiple jurisdictions have surged. Such anti-competitive practices have harmful consequences for society at large, and therefore can create private obstacles to market access nullifying the advances made by governments in trade liberalisation and regulatory reform. These issues could be potentially solved through international competition law mechanism. Harmonisation is arguably desirable for its efficiency effects, which, for instance, can reduce the burdensome costs of legal uncertainty imposed by divergent local standards. The EU among other countries have advocated in favour of the harmonisation or internationalisation of competition law, most notably under the auspices of the WTO. This is because the WTO has a near universal membership; it can provide a balanced response sensitive to the varying interests and concerns of both developed and developing countries; the WTO is the recognised institution for trade related international economic rules, which are closely related to competition issues (some of its Agreements already have a number of specific provisions to address anticompetitive practices, i.e. in the area of antidumping); the institutional infrastructure of the WTO includes a system of transparency and surveillance through notification requirements and monitoring provisions; it contains the general rules relating to non-discrimination and transparency; the WTO also provides a forum for continuous negotiation and consultation, where its members could bring their trade-related competition concerns; 
and most importantly the WTO has a well established, reinforced and legalised dispute settlement mechanism between governments ${ }^{17}$.

Presuming that the WTO is the best body for the job, it can provide the following benefits with regard to international competition issues. First of all, Brittan and Van Miert expressed that international competition rules may help tackle market access issues. For instance, anti-competitive practices keep European firms out of third country markets and they cannot, in the absence of proper enforcement measures in those third country markets, be effectively dealt with without international rules. European firms also face a competitive disadvantage if they have to compete on world markets with foreign producers operating from home markets that are subject to lax competition policies. In this context multilateral rules would promote more equal conditions of competition world-wide.

Secondly, international competition rules can help to avoid conflicts of law and jurisdiction between countries and to promote a gradual convergence of competition laws ${ }^{18}$. As aforementioned, some competition authorities, including the EU and US, apply the 'effect doctrine' to deal with international anti-competitive practices assuming jurisdiction even if all the conduct complained of takes place in other countries. However, jurisdiction is a central and vital attribute of state sovereignty; a country is able to enact and enforce laws within its boundaries and must not intervene in the domestic affairs of other nations. Thus, the issues of public international law may arise here, where public international law sets down rules to limit a state's exercise of government functions in another forum. The problem is that some countries may not appreciate extra-territorial reach into their domestic competition law system, especially if they do not have a similar belief as to what constitutes anti-competitive harm. Sovereignty concerns may limit the potential

\footnotetext{
17 Communication submitted by Sir Leon Brittan and Karel Van Miert towards an international framework of competition rules Communication to the Council, Com(96)284, available from web-site: http://ec.europa.eu/comm/competition/international/com284.html. Also, see M. Dabbah, The Internationalisation of Antitrust policy, Cambridge university press, 2003, pp. 224.

${ }^{18}$ Communication submitted by Sir Leon Brittan and Karel Van Miert towards an international framework of competition rules Communication to the Council, Com(96)284
} 
benefits of extra-territoriality ${ }^{19}$. It means that national competition authorities may fall short of providing a remedy when more than one jurisdiction is involved, especially when it comes to collecting information and evidence from foreign countries. This is why there is a real need to minimise the jurisdictional conflicts, not only from the extra-territorial application of certain competition laws, but also from the application of competition law to anti-competitive practices conceived abroad but implemented within one's jurisdiction.

Thirdly, apart from sovereignty concerns, other problems can also occur in the application of the 'effect doctrine' by various competition authorities. The same international transaction can be subjected to different competition authorities which imposes conflicting obligations on firms. One might say that firms in question need simply to confirm their conduct to whichever competition law regime is more restrictive. However, this can lead to global overregulation ${ }^{20}$. Furthermore, conflict in policy objectives may also occur, for instance, in the cases where one country allows certain conduct generally agreed on the conclusion that its pro-competitive effects are likely to outweigh any anti-competitive concerns. For another country to restrict that conduct is thus to deny those pro-competitive effects to the first nation, which is contrary to its policy preferences. This can instigate policy conflicts where countries differ on what counts as pro-competitive effects and to what extent they should be taken into consideration ${ }^{21}$. Convergence of competition laws can reduce contradictory decisions (or duplicative proceedings) and therefore curtail firms' costs and time of compliance with competition laws or any conflicts in their competition policies and most importantly increase the legal certainty for firms operating in different jurisdictions.

Finally, there is the necessity for an international instrument with a binding notion to respond to globalisation and trans-national transactions. This is because the non-binding nature of current agreements might not always provide satisfactory results. Many countries which have implemented comprehensive competition policies, nonetheless, lack the necessary knowledge, experience or even resources to apply domestic competition rules to anti-competitive practices with an international

\footnotetext{
${ }^{19}$ D. Sokol, Monopolists without borders: the Institutional Challenge of International Antitrust in a Global Gilded Age, Berkeley Business Law Journal, Vol. 4.1, 2007, pp. 46.

${ }^{20}$ Suggested by Elhauge and Geradin, Global Competition Law and Economics, Hart, 2007, pp.10111012.

${ }^{21}$ For further discussion, see Elhauge and Geradin, Global Competition Law and Economics, Hart, 2007, pp.1011-1012.
} 
dimension. Lack of any competition laws in a number of jurisdictions worldwide adds to further international problems. All these issues suggest the importance and necessity for international competition law rules. However, these benefits do not come without costs. Thus, the following section will examine what are the pitfalls of international competition law harmonisation.

\section{“One size fits all” - the pitfalls of international competition law harmonisation and the WTO}

The WTO provides a framework of binding rules together with an effective dispute resolution mechanism, however, with the raison d'être being solely that of global trade policy. Competition policy intersects with trade policy when anticompetitive practice eliminates a foreign firm from a national market as effectively as a high tariff would, and when the national competition authority fails to provide a remedy for such conduct. Although international trade and competition policy are inter-related, this does not necessarily mean that the WTO is well equipped to take on anti-competitive issues. In contrast, the past proves that the WTO in its present capacity is incapable of dealing with competition issues satisfactorily. For instance, the Kodak-Fuji ${ }^{22}$ and Telmex ${ }^{23}$ cases show that the WTO was unable to properly address the problems of anti-competitive practices which foreclose market access. The WTO panel had a difficult dilemma to deal with the complex issue of private agreements and hybrid government-private restrictions (as the new barriers to a liberalised marketplace) in the absence of international competition rules and out of reach of international trade law as well as national competition laws. These cases suggest that in the situations where there is an interaction between private anticompetitive practices and government measures involved, the WTO panel may exhibit a more cautious engagement of trade tools to address anti-competitive issues $^{24}$. These examples also highlight the main differences between trade and competition policies; trade rules address governmental practices as opposed to the anti-competitive conduct by private firms covered under competition law. Along

\footnotetext{
${ }^{22}$ WTO Japan - Measures affecting consumer photographic film and paper, 31 March 1998, WT/DS44/R

${ }^{23}$ WTO Mexico - Measures affecting Telecommunications Services 2 April 2004, WT/DS204/R

${ }^{24}$ For further discussion, see K. Lee, The WTO dispute settlement and anti-competitive practices: lessons learnt from trade disputes, the University of Oxford press, Working paper, 10/05.
} 
similar lines, the differences in objectives may even further the problem. The WTO's main task is to deal with trade policy, which is mainly concerned with market-access. If the scope of the WTO was extended to include competition rules (as suggested by some scholars ${ }^{25}$ ), then it may appear that competition policy at the WTO would be overwhelmed by the market access norms of trade policy at the expense of distorting the consumer welfare norm of competition law and policy, especially if there was a conflict between them, the WTO would most likely decide in favour of trade norms. No matter how these two sets of norms reconcile in theory, they cannot work happily in practice. ${ }^{26}$ This might suggest that a clear set of rules should be reached with the boundaries being made between trade and competition policies. Otherwise, when there is an overlap in competition and trade policy issues, different conclusions may be reached regarding the effect of a particular restraint.

The nature of competition issues is too complex to be cast in a binding international regime established and enforced by a dispute settlement body, such as the WTO which lacks the legitimacy and expertise to manoeuvre the difficult analytical tools of competition law. Lee argues that to allow WTO tribunals to exercise a judicial-creating or gap-filling role would stagger the legitimacy of not only the dispute settlement mechanism but also of the WTO system as a whole ${ }^{27}$. Along similar lines, Professor Jackson claims that the use of WTO tribunals to resolve competition policy disputes to "plug gaps" in the WTO agreement "places too much of the problem-solving burden on the dispute settlement process". ${ }^{28}$ However, other scholars like Hansen have faith in the WTO and argues that the WTO can and should step into the legal gap concerning competition policy in order to safeguard the international trading system ${ }^{29}$. Furthermore, she suggests that a rule requiring governments to negotiate an adjustment for their policies that contain a

\footnotetext{
${ }^{25}$ See, for instance, P. Hansen, Antitrust in the Global Market: Rethinking "Reasonable Expectations”, 72 Southern California Law Review, 1601, 1999. M. Dabbah, The Internationalisation of Antitrust policy, Cambridge university press, 2003, pp. 224-225, ch.9.

${ }^{26}$ For further discussion, see DK Tarullo, Norms and Institutions in Global Competition Policy, The American Journal of International Law, Vol. 94, No. 3, 2000, pp. 478-504

${ }^{27}$ K. Lee, The WTO dispute settlement and anti-competitive practices: lessons learnt from trade disputes, the University of Oxford press, Working paper, 10/05.

${ }^{28}$ In: Expert Warns of Burden to WTO Dispute Settlement, 15 Int'l Trade Rep. (BNA) No. 18, at 778 May 6, 1998.

${ }^{29}$ P. Hansen, Antitrust in the Global Market: Rethinking "Reasonable Expectations”, 72 Southern California Law Review, 1601, 1999.
} 
disproportionate impact on imports is consistent with the text and purpose of the WTO. It is possible that governmental tolerance towards restrictive business practices could render existing commitments reached at the WTO meaningless, and encourage the behaviour that WTO rules were designed to prevent. The absence of specific rules for competition places a difficult task on the WTO tribunal to resolve disputes over these policies. However, the author disagrees that the WTO should stretch its powers in order to cover competition issues without having a consensus by its members on what competition rules should be, in what forms, and to what extent they should be addressed in international trade disputes?

International anti-competitive practices bring nations of different economic development into contact with one another. Countries do not share common competition policy traditions; some of them do not even have any competition laws in place. Considering the complex nature of competition, reaching an agreement among many countries with too diverging competition cultures becomes a formidable task. For instance, the model of competition law from developed countries is not necessarily ideal for small, emerging market economies, or developing countries. It has been suggested that developed countries first developed an industrial policy and then modified it in the light of international commitments. During times of rapid structural change, developed countries could modify their competition policy to facilitate necessary changes; however, the same is not possible for economies in transition due to their international obligations and imposed models from the developed countries ${ }^{30}$. Parachuting competition laws from developed countries on developing countries would mean that they will not be able to develop competition rules to suit their own legal, economic and political conditions. Similarly, small market economies require different competition rules, as laxer competition rules. This is because there are a limited number of market players in small markets that the market can serve and in order for these countries to achieve economies of scale they would require to have more concentrated markets. ${ }^{31}$ Although the WTO to some extent addresses specific features of developing and less developed countries with regard to trade issues, it is not clear to what extent the specific attributes of

\footnotetext{
${ }^{30}$ F. Vissi, Challenges and Questions around Competition Policy: the Hungarian Experience, 1995, 18 Fordham International Law Journal 1230. Also, see M. Dabbah, The Internationalisation of Antitrust policy, Cambridge university press, 2003, pp. 126-129.

${ }^{31}$ Gal, Competition policy for small market economies, Harvard University press, 2003.
} 
developing or small countries would be taken into consideration vis-à-vis competition issues.

Finally, benefits and costs analysis should also be mentioned. It may be the case that an international competition law agreement is not worth having if the gains to achieve it are outweighed by the implementation costs. Although there is a demand for international competition law, but in relation to the costs of an international regime, the benefits could be just too small. It has to be taken into account that each nation would have to deviate from its competition policy (presumably tailored to serve its needs) to compromise on a common international regime ${ }^{32}$.

To summarise, an 'ideal' model, which assumes that "one size fits all” is unlikely to be created in the near future. The differences in competition law and policies and economic development between nations make the harmonisation an ambitious task that requires outstanding efforts from all members to reach consensus on multilateral agreement.

\section{Conclusion}

International competition law addresses complex issues. On the one hand, the globalisation process therefore international anti-competitive practices have initiated the negotiation of international competition rules and their importance. International competition law mechanism could cover global anti-competitive transactions unreachable by domestic competition authorities. It could eliminate contradictory decisions from different jurisdictions, and save time and costs for firms involved in international transactions, as well as provide legal certainty and transparency. However, on the other hand, reaching an agreement among many countries with too diverging competition cultures and at different development scales becomes a formidable task. Countries do not share common competition policy traditions; the model that suits developed countries is not necessarily ideal for developing countries. Although the WTO with its well established dispute resolution mechanism has its benefits, the lack of consensus among the nations on international competition policy and law suggests that an international system of antitrust is unlikely to appear on the horizon in the near future.

\footnotetext{
${ }^{32}$ For further discussion, see Elhauge and Geradin, Global Competition Law and Economics, Hart, 2007, pp.1011-1012.
} 